\title{
Pelagic-benthic coupling on the shelf of the northern Bering and Chukchi Seas. II. Benthic community structure
}

\author{
Jacqueline M. Grebmeier*, Howard M. Feder, C. Peter McRoy \\ Institute of Marine Science, University of Alaska Fairbanks, Fairbanks, Alaska 99775-1080, USA
}

\begin{abstract}
Benthic fauna abundance, biomass and diversity were investigated in the northern Bering and Chukchi Seas to determine factors influencing faunal distribution in this polar region. The hypothesis tested whether sediment grain size and water mass characteristics, such as organic carbon supply to the benthos and temperature, are regulating factors in benthic community structure. Benthic communities under the cold, highly productive $\left(-250\right.$ to $\left.300 \mathrm{~g} \mathrm{C} \mathrm{m}^{-2} \mathrm{yr}^{-1}\right)$ Bering Shelf-Anadyr Water (BSAW) are dominated by a high biomass of amphipods ( $F$. Ampeliscidae and F. Isaeidae) and bivalves (F. Nuculidae and F. Tellinidae). A diverse, low biomass fauna exists in benthic communities under the warmer, less productive $\left(\sim 50 \mathrm{~g} \mathrm{C} \mathrm{m}^{-2} \mathrm{yr}^{-1}\right)$ Alaska Coastal Water $(\mathrm{A} . \mathrm{CW})$, including amphipods (F. Isaeidae and F. Ampeliscidae), bivalves ( $F$. Tellinidae and $F$. Thyasiridae), polychaetes (F. MaIdanidae and Nephtyidae), and sand dollars (F. Echinarachniidae). Faunal diversities are lowest for stations under BSAW, characterized by high food supply and moderately homogeneous (well-sorted), sandy sediments. Highest diversities occur at stations in ACW, which is characterized by low food supply and a more heterogeneous (poorly-sorted) mixture of silt and clay, sand and gravel sediments. Faunal diversity also increased to the north in the Chukchi Sea, where food availability in the bottom water and surface sediments was greater and more heterogeneous, finer-grain sediments occur. The findings indicate that sediment heterogeneity, silt and clay fractions, and temperature are major regulating factors on benthic community structure, with each positively influencing faunal diversity. Lower diversity was correlated to an increase in fine sand fractions. Food supply, both in the bottom water and surface sediments, has a more variable influence on benthic community structure, although it has a direct positive influence on benthic biomass.
\end{abstract}

\section{INTRODUCTION}

Shallow marine benthic systems in polar regions can exhibit high faunal abundances and biomass in spite of low temperatures and seasonal, spring and summer, fluxes of particulate organic matter to the benthos (White 1977, Petersen \& Curtis 1980, Grebmeier 1987). An important question in marine ecology concerns the mechanisms that regulate benthic community structure (Valiela 1984). In Arctic and Antarctic benthic fauna, slow growth and long life spans, along with variable food supplies and diverse substrate conditions, are factors known to influence benthic faunal abundance and biomass (White 1977, 1984, Clarke 1980, Petersen \& Curtis 1980, Feder \& Jewett 1981, Stoker 1981, Grebmeier 1987).

\footnotetext{
- Address for correspondence: Graduate Program in Ecology, University of Tennessee, Knoxville, Tennessee 37996-1610, USA
}

Past studies in shallow regions of the Bering and Chukchi Seas indicate that high benthic abundance and biomass values often correspond to areas of enhanced deposition of phytodetritus to the benthos, particularly in low temperature, high salinity water mass regimes (Haflinger 1981, Stoker 1981, Feder at al. 1985). A synoptic view of the location of major water masses during the summer, water column chlorophyll a concentrations, differences in annual primary production, and variance in benthic community structure and biomass in the northern Bering and Chukchi Seas indicates a strong coupling between water mass characteristics, food supply and benthic processes (Grebmeier 1987). In the present study, we examine the distribution, diversity and biomass of benthic stations combined by similarity analysis of faunal abundance in relation to hydrographic and sediment characteristics.

Hydrographic characteristics on the shallow shelf $(<50 \mathrm{~m})$ of the northern Bering and Chukchi Seas have 


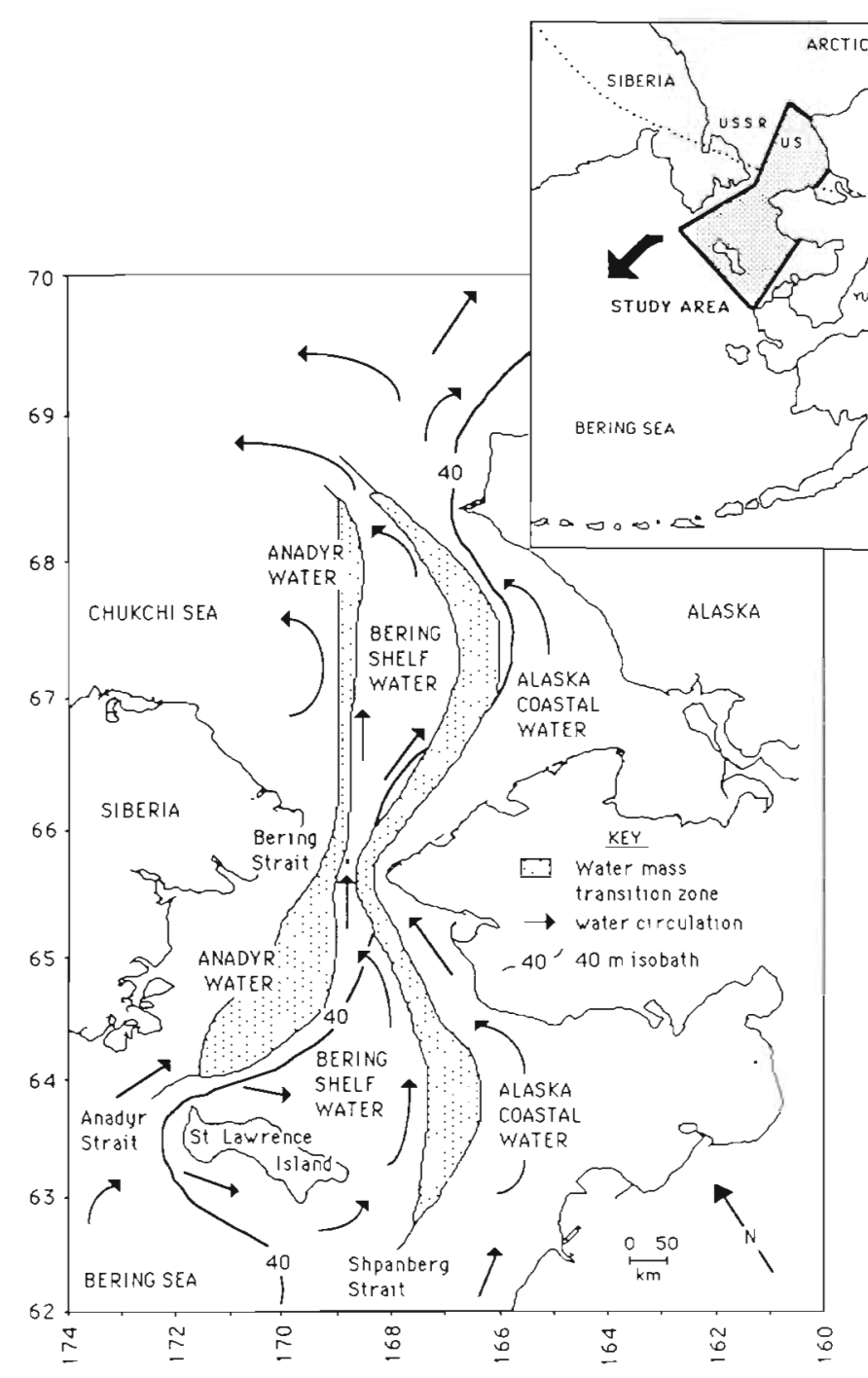

been described previously (Grebmeier 1987, Grebmeier et al. 1988; Fig. 1). This area contains 3 northward-flowing water masses: the Anadyr and Bering Shelf waters, forming a modified Bering Shelf-Anadyr Water (BSAW) to the west, characterized by low temperatures $\left(-1\right.$ to $\left.+2.0^{\circ} \mathrm{C}\right)$ and relatively high salinity $(>31.8 \%)$, and Alaska Coastal Water $(\mathrm{ACW})$ to the east, characterized by higher temperatures $\left(>+2{ }^{\circ} \mathrm{C}\right)$ and lower salinity $(<31.8 \%$; Coachman et al. 1975 , Coachman 1987). BSAW has an estimated annual primary production of 250 to $300 \mathrm{~g} \mathrm{C} \mathrm{m}^{-2}$ compared to an annual primary production of $50 \mathrm{~g} \mathrm{C} \mathrm{m}^{-2}$ in $\mathrm{ACW}$ (Sambrotto et al. 1984, Walsh et al. 1987, Springer 1988). The central regions of the northern Bering Sea are characterized by fine and very fine sand, with coarser grained sand, gravel and cobbles near the outer boundaries of the northern Bering Sea, also known as the Chirikov Basin, and in the Anadyr and Bering Straits (Creager \& McManus 1967, McManus et al.
Fig. 1. Study area in the northern Bering and Chukchi Seas showing local water circulation, water masses, and bathymetry (modified from Coachman et al. 1975, Nelson et al. 1981, and Coachman 1987)

1977, Grebmeier 1987; Fig. 1). In comparison, offshore regions in the Chukchi Sea are characterized by very fine sand and silt and clay sediments (McManus \& Smyth 1970, McManus et al. 1977, Grebmeier 1987).

Stoker (1981) reported differences in benthic community structure between the coastal and offshore regions of the northern Bering and Chukchi Seas. He described the benthos along the Alaska coast as one with a low biomass of polychaetes, bivalves, and echiuroids, while the offshore region was characterized by a high biomass of amphipods and different species of bivalves. Although Stoker qualitatively concluded that species distribution and biomass were correlated with substrate type, he had limited environmental data. He proposed 4 potential factors which could influence benthic structure and biomass: primary productivity, terrestrial detrital input, current regimes, and distribution of predators. In a related study (Grebmeier et al. 1987), we concluded that benthic biomass in this region is responsive to the quality and quantity of organic carbon reaching the benthos from the overlying water column in the northern Bering and Chukchi Seas. In this study we investigate the effect of food supply on faunal abundance and diversity and the role of other environmental variables on benthic community structure.

Food supply from high primary production has been proposed as a regulating factor in benthic community structure in shallow marine waters in the Antarctic (Clarke 1980). Dayton \& Oliver (1977) found benthic abundance was highest on the east side of McMurdo Sound under eutrophic waters compared to low faunal abundance in the oligotrophic west side of the Sound. Stewart et al. (1985) suggested that the benthic faunal groupings they observed on the Canadian continental shelf and slope corresponded the best with major water mass and temperature regimes in the area, although no water column primary production or phytoplankton biomass were investigated.

Sediment grain size composition plays an important 
role in determining the structure of benthic communities (Gray 1981). For example, Fresi et al. (1983), in a study off the coast of Italy, demonstrated that zonation of benthic communities correlated most strongly with sediment structure, interpreted as a reflection of water motion gradients. Heterogeneous sediments have been implicated as influences of high benthic faunal diversities in the Gulf of St Lawrence, as well as water temperature and depth (Long \& Lewis 1987). In another study in the Gulf of St Lawrence, Robert (1979) proposed that species richness increased with sand content, regardless of associated water depth. The percentage of very fine sand and the combined silt and clay fraction have been shown to differentiate biotic assemblages on the continental shelf off North Carolina (Weston 1988). This study also demonstrated the importance of sediment sorting in determining dominant fossorial (tube-building) species. We hypothesize that both sediment heterogeneity and water characteristics are regulating factors in community structure in the northern Bering and Chukchi Seas.

\section{MATERIALS AND METHODS}

Water column and benthic sampling occurred in the northern Bering and Chukchi Seas during the openwater season (Fig. 1). Four replicate $0.1 \mathrm{~m}^{2}$ van Veen grabs (weighted with $32 \mathrm{~kg}$ lead) were taken at each station for sampling the benthos. Samples were washed on $1 \mathrm{~mm}$ sieve screens, preserved in $10 \%$ hexamethyltetramine-buffered formalin, stored in plastic Whirl-pak ${ }^{T M}$ bags, and saved for laboratory analysis. Animals were identified to family level, counted, and weighed to determine abundance and wet weight biomass. Previous work in this region has shown that only 1 to 5 species occurred in each dominant family, with a majority of families containing only 1 or 2 species (Stoker 1981, Grebmeier 1987). Therefore, the familial level determinations were considered an adequate measure of faunal composition and the clustering program presented a valid methodology for analysis. Preserved wet weight biomass was converted to carbon biomass using the conversion values of Stoker (1978) following the method of Grebmeier (1987).

Highly motile epifaunal organisms (crabs, predatory gastropods and sea stars) were excluded from the analysis. Stations dominated by relatively sessile and sessile epifaunal organisms, such as sea anemones, barnacles, bryozoans, and sea urchins were included. Colonial organisms (sponges, sea anenomes, and ectoprocts) were given an abundance count of 1 for each colony observed. Fragments were given an abundance value of 1 and then weighed as a sum total of fragments for that taxon determination. The van Veen grab was unable to capture deep-dwelling bivalves, Myidae and Mactridae, a problem also recognized by previous workers (Stoker 1981, Feder et al. 1985).

Abundance data were used in a numerical clustering program to group stations according to faunal similarities (Stoker 1981, Feder et al. 1985). The program clusters stations on the basis of similarities in relative percent of faunal composition using the Czekanowski similarity coefficient (Stephenson et al. 1972). Log transformations of abundance data $[\ln (x+1)]$ were used because the Czekanowski coefficient is sensitive to extremely large abundance values (Boesch 1973), which occurred in our data. A mean biomass was calculated for station groups by determining the mean of the stations combined by cluster analysis.

The Shannon-Weaver indices of diversity $\left(H^{\prime}\right)$ and evenness ( $\mathrm{J}$ ) were determined for stations and station cluster groups, based on families, following the methodology of Long \& Lewis (1987). Family diversity and evenness are used in comparisons of station groups within defined water types.

Sediment samples were collected with a Haps corer or MK3 box corer. Subsamples were taken with either 6 or $13 \mathrm{~cm}$ diameter plexiglas cores, $26 \mathrm{~cm}$ long, and frozen for later laboratory analysis. Based upon indications at a subset of stations in both BSAW and ACW that there was no change of sediment grain size with depth in the top 5 to $10 \mathrm{~cm}$, only surface sediment values were used. Surface sediments $(0$ to $1 \mathrm{~cm})$ were sectioned, dried, homogenized and sampled for sediment grain size analysis by dry sieving, using standard geological sieves ( -1 and 1 to 4 phi sizes) and a Ro-tap machine (Folk 1980). Sediments were weighed after sieving and a modal sediment size and percent composition calculated.

A sediment sorting coefficient (Graphic Standard Deviation) was calculated and represents the degree of mixing of different sediment types (Gray 1981). Wellsorted sediments, indicative of homogeneous sediments, normally occur in high energy areas, while poorly-sorted sediments, indicative of heterogeneous sediments, normally occur in low energy areas. A ranking of sediment heterogeneity based on sorting coefficients was determined for all stations using the index presented in Fig. 2.

Correlations between station variables and sediment parameters were investigated using both parametric (Pearson product-moment $I$ ) and nonparametric (Spearman's rho) correlation tests. Parametric tests were utilized when a large enough sample size was available to assume a normal distribution. A microcomputer statistical package was utilized (BrainPower Inc. 1985) 
and test statistics were evaluated using standard tables (Rohlf \& Sokal 1969, Conover 1980).

Bottom salinity, temperature, depth and chlorophyll a biomass data were obtained in conjunction with other investigators using a Niel Brown conductivity-temperature-depth (CTD) profiler and Nisken rosette (McRoy \& Tripp 1986, 1987). The method for determining total organic carbon (TOC) and nitrogen (TON) for surface sediments and the subsequent data used in this study have been described elsewhere (Grebmeier 1987 , Grebmeier et al. 1988). Station numbers are presented as the 2-digit cruise number followed by the 3-digit consecutive station number for that cruise.

\section{RESULTS}

Benthic stations were occupied over 3 field seasons from July to September in the years 1984 to 1986 using the RV 'Alpha Helix'. Temperature and salinity data confirm presence of a front dividing Bering ShelfAnadyr Water (BSAW) from Alaska Coastal Water (ACW; Coachman 1987). The average location of the seasonal front was used to designate station locations relative to BSAW and ACW. Hydrographic data, along with benthic faunal abundance, biomass, diversity and evenness, were analysed for 49 stations (Fig. 3, Table 1). Surface sediments were collected at 33 of these stations and modal size class, grain size composition, sorting coefficients and sediment heterogeneity were subsequently determined (Table 2).

\section{Sediment composition}

The percent composition of various grain size classes in the surface sediments showed a separation of stations between the northern Bering and Chukchi Seas (Fig. 4). A majority of the Bering Sea stations were in the $>70 \%$ sand substrate class, while those in the Chukchi Sea are near the 50\% sand/silt and clay sediment class. Stations with highest coarse sand and gravel content typically are in ACW in both the northern Bering and Chukchi Seas.

There were significant correlations between surface sediment TOC and TON and percent silt and clay, percent fine sand, and sediment heterogeneity, based on sediment sorting (Table 3). Surface sediment TOC and TON are positively correlated with percent silt and clay, which was highest in the Chukchi Sea, and were negatively correlated with increasing percent fine sand, the major sediment type in the northern Bering Sea (Fig. 4). Sediment sorting and heterogeneity were positively correlated with TOC and TON (Table 3).

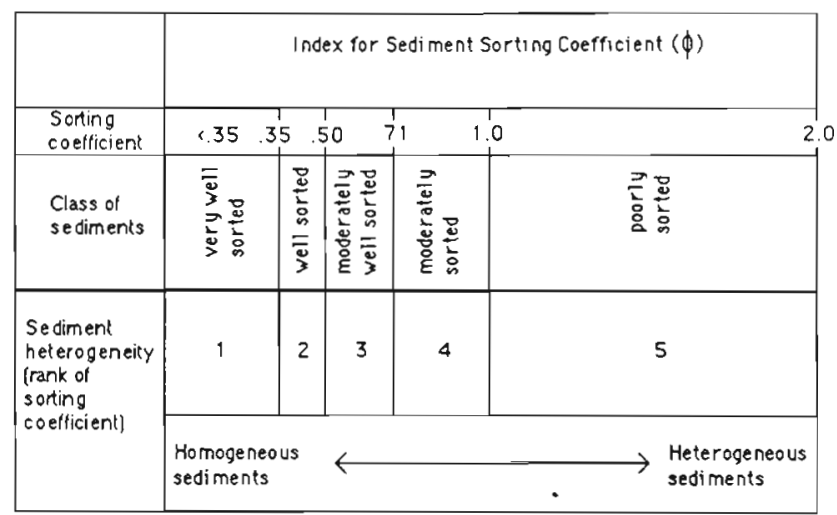

Fig. 2. Index for sediment sorting coefficients (from Gray 1981), the corresponding class of sediment, and an associated gradient to rank sediment sorting in relation to sediment heterogeneity

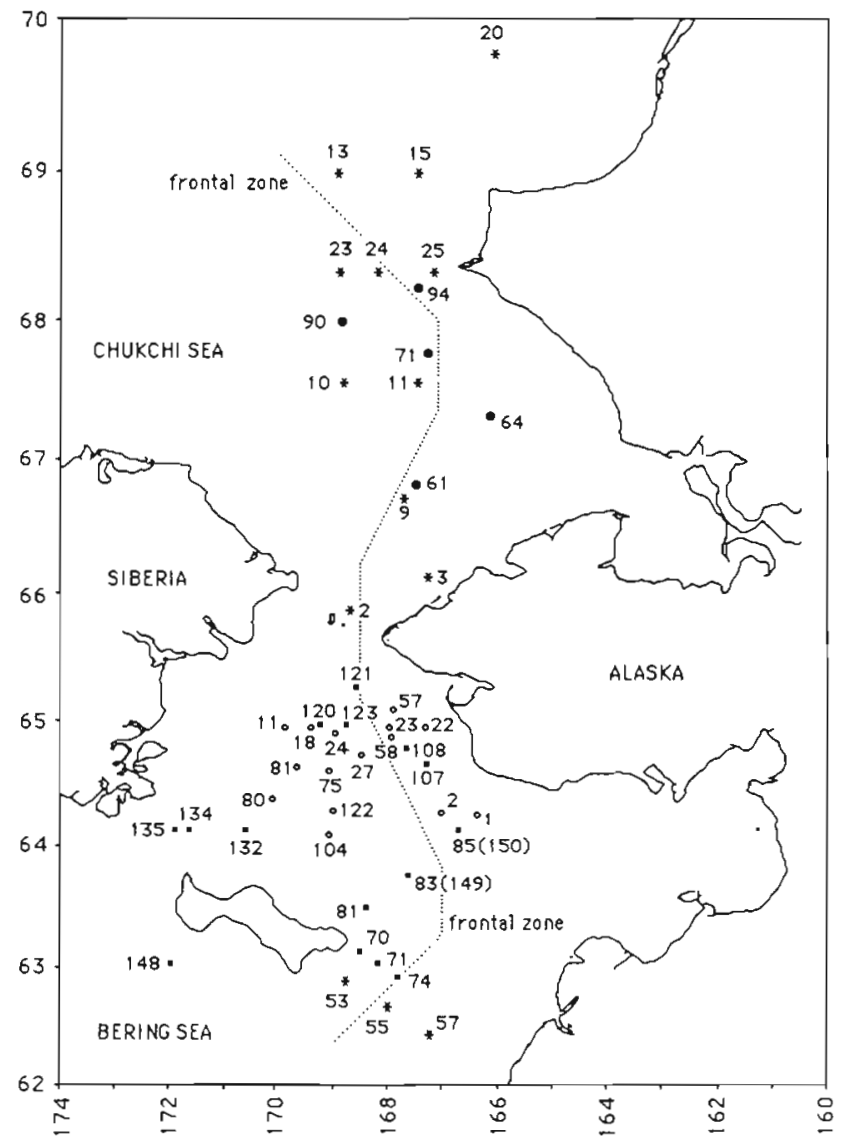

Fig. 3. Location of benthic sampling stations in the northern Bering and Chukchi Seas for Cruises 59 (-), 73 (o), 74 (*) and 85 (•). A frontal zone separates Bering Shelf-Anadyr Water in the west from Alaska Coastal Water in the east

\section{Benthic community structure}

A total of 60 faunal families comprised $95 \%$ of the ranked abundance and biomass during the study (Table 4); many different families comprise the remain- 
Table 1. Summary of station hydrographic and biological measurements for Cruises $59,73,74$ and 85 in the northern Bering and Chukchi Seas. Benthic faunal diversity $\left(H^{\prime}\right)$ and evenness $(J)$ were calculated from the abundance data. Blanks: no data available

\begin{tabular}{|c|c|c|c|c|c|c|c|c|}
\hline \multirow[t]{2}{*}{ Station } & \multirow{2}{*}{$\begin{array}{c}\text { Bottom } \\
\text { temp. }\left({ }^{\circ} \mathrm{C}\right)\end{array}$} & \multirow{2}{*}{$\begin{array}{c}\text { Bottom } \\
\text { salinity }(\%=0)\end{array}$} & \multirow{2}{*}{$\begin{array}{l}\text { Bottom } \\
\text { sigma-t }\end{array}$} & \multirow{2}{*}{$\begin{array}{l}\text { Depth } \\
(m)\end{array}$} & \multicolumn{2}{|c|}{ Benthic } & \multirow[t]{2}{*}{$H^{\prime}$} & \multirow[t]{2}{*}{$J$} \\
\hline & & & & & $\begin{array}{l}\text { Abundance } \\
\text { (ind. } \mathrm{m}^{-2} \text { ) }\end{array}$ & $\begin{array}{c}\text { Biomass } \\
\left(\mathrm{g} C \mathrm{~m}^{-2}\right)\end{array}$ & & \\
\hline 59070 & -0.98 & 33.429 & 26.88 & 26 & 313 & 22.9 & 2.22 & 0.75 \\
\hline 59071 & -0.24 & 33.229 & 26.69 & 20 & 463 & 18.6 & 1.01 & 0.40 \\
\hline 59074 & 0.00 & 33.237 & 26.68 & 19 & 140 & 2.6 & 2.42 & 0.87 \\
\hline 59081 & -0.68 & 33.412 & 26.85 & 25 & 900 & 13.7 & 2.02 & 0.74 \\
\hline 59107 & 0.16 & 33.377 & 26.79 & 27 & 7770 & 2.0 & 0.61 & 0.20 \\
\hline 59108 & -0.16 & 33.183 & 26.65 & 36 & 315 & 3.0 & 1.69 & 0.61 \\
\hline 59120 & -0.21 & 32.750 & 26.30 & 47 & 7383 & 32.2 & 0.89 & 0.28 \\
\hline 59121 & 0.82 & 32.635 & 26.15 & 50 & 2865 & 29.5 & 1.13 & 0.34 \\
\hline 59123 & 0.07 & 33.030 & 26.51 & 49 & 5548 & 26.8 & 0.74 & 0.22 \\
\hline 59132 & 0.90 & 32.309 & 25.89 & 31 & 188 & 20.9 & 1.16 & 0.59 \\
\hline 59134 & -0.72 & 32.677 & 26.26 & 51 & 1558 & 11.3 & 0.90 & 0.32 \\
\hline 59135 & 0.80 & 32.517 & 26.06 & 43 & 1810 & 13.7 & 1.14 & 0.37 \\
\hline 59148 & -0.67 & 33.101 & 26.63 & 55 & 2293 & 13.3 & 2.59 & 0.76 \\
\hline 59149 & -0.46 & 33.368 & 26.81 & 31 & 3195 & 9.0 & 1.47 & 0.48 \\
\hline 59150 & -0.33 & 33.257 & 26.71 & 30 & 1190 & 10.4 & 2.64 & 0.76 \\
\hline 73001 & 1.10 & 32.197 & 25.79 & 24 & 1418 & 7.4 & 2.91 & 0.78 \\
\hline 73002 & 1.89 & 32.168 & 25.71 & 26 & 1190 & 8.5 & 2.86 & 0.75 \\
\hline 73011 & 0.31 & 32.656 & 26.20 & 45 & 5845 & 19.7 & 0.99 & 0.29 \\
\hline 73018 & 0.71 & 32.646 & 26.17 & 42 & 7628 & 21.3 & 0.98 & 0.28 \\
\hline 73022 & - & - & - & 26 & 1535 & 1.8 & 0.99 & 0.32 \\
\hline 73023 & - & - & - & 42 & 2510 & 22.3 & 3.04 & 0.77 \\
\hline 73024 & - & - & - & 44 & 6398 & 25.9 & 1.44 & 0.42 \\
\hline 73027 & 1.25 & - & - & 40 & 8605 & 12.8 & 1.75 & 0.49 \\
\hline 73057 & 2.62 & 32.313 & 25.77 & 31 & 305 & 1.0 & 2.37 & 0.82 \\
\hline 73058 & 0.88 & 32.432 & 25.99 & 28 & 5785 & 2.9 & 0.81 & 0.23 \\
\hline 73075 & 1.12 & 32.779 & 26.25 & 43 & 8908 & 24.5 & 1.25 & 0.34 \\
\hline 73080 & 1.47 & 32.774 & 26.23 & 40 & 1668 & 17.7 & 2.15 & 0.63 \\
\hline 73081 & 1.42 & 32.840 & 26.28 & 42 & 3245 & 17.4 & 1.82 & 0.57 \\
\hline 73104 & 1.88 & 32.522 & 26.00 & 34 & 14365 & 20.1 & 1.35 & 0.39 \\
\hline 73122 & 2.13 & 32.777 & 26.18 & 40 & 5555 & 14.0 & 1.24 & 0.37 \\
\hline 74002 & 2.56 & 32.428 & 25.87 & 49 & 1080 & 11.6 & 3.16 & 0.84 \\
\hline 74003 & 8.58 & 28.207 & 21.87 & 22 & 2765 & 3.2 & 1.80 & 0.51 \\
\hline 74009 & 4.79 & 32.149 & 25.44 & 32 & 2623 & 4.6 & 2.45 & 0.70 \\
\hline 74010 & 3.01 & 32.719 & 26.06 & 48 & 9188 & 59.0 & 2.00 & 0.56 \\
\hline 74011 & 3.27 & 32.591 & 25.94 & 46 & 2548 & 15.1 & 2.25 & 0.73 \\
\hline 74013 & 2.70 & 32.850 & 26.19 & 51 & 488 & 1.3 & 2.19 & 0.73 \\
\hline 74015 & 3.62 & 32.378 & 25.74 & 46 & 890 & 1.7 & 2.20 & 0.75 \\
\hline 74020 & 4.71 & 32.064 & 24.38 & 42 & 545 & 9.9 & 2.23 & 0.77 \\
\hline 74023 & 2.64 & 32.692 & 26.07 & 53 & 2068 & 20.1 & 2.16 & 0.64 \\
\hline 74024 & 2.85 & 32.421 & 25.84 & 49 & 2178 & 7.9 & 2.43 & 0.69 \\
\hline 74025 & 8.51 & 30.847 & 23.94 & 37 & 193 & 3.9 & 2.49 & 0.88 \\
\hline 74053 & -0.23 & 32.199 & 25.86 & 38 & 7923 & 16.7 & 1.75 & 0.52 \\
\hline 74055 & 1.47 & 31.883 & 25.51 & 30 & 4423 & 4.5 & 2.59 & 0.69 \\
\hline 74057 & 7.29 & 31.488 & 24.62 & 25 & 2370 & 8.3 & 2.73 & 0.79 \\
\hline 85061 & 5.80 & 32.300 & 25.44 & 28 & 2433 & 7.4 & 2.76 & 0.80 \\
\hline 85064 & 3.73 & 32.254 & 25.63 & 35 & 785 & 1.7 & 2.86 & 0.90 \\
\hline 85071 & 2.03 & 32.517 & 25.98 & 54 & 2048 & 8.5 & 2.68 & 0.78 \\
\hline 85090 & 2.97 & 32.741 & 26.08 & 54 & 12115 & 32.4 & 2.49 & 0.69 \\
\hline 85094 & 4.71 & 32.135 & 25.44 & 45 & 687 & 19.2 & 3.14 & 0.86 \\
\hline
\end{tabular}

ing $5 \%$. The cluster analysis delineated 11 station groups (Figs. 5 and 6 ). Six of the 49 stations did not combine with other stations and were deleted from further analysis. The majority of the multiple station groups clustered at the 43 to $76 \%$ level.

Groups I, III, IV and XI all occur under BSAW and have abundance values ranging from 1684 to 6940 ind. $\mathrm{m}^{-2}$ and biomass values ranging from 11.3 to $24.2 \mathrm{~g} \mathrm{C} \mathrm{m}^{-2}$ (Table 5). Groups I (northern Bering Sea) and III (Chukchi Sea) are comprised of stations primarily located in the central basins of BSAW and have the highest abundance (5365 to 6940 ind. $\mathrm{m}^{-2}$ ) and biomass ( 22.2 to $24.2 \mathrm{~g} \mathrm{C} \mathrm{m}^{-2}$ ) 
Table 2. Summary of station sediment measurements for Cruises $59,73,74$, and 85 . SC: sorting coefficient; SH: sediment heterogeneity; TOC: total organic carbon; TON: total organic nitrogen

\begin{tabular}{|c|c|c|c|c|c|c|c|c|c|c|c|}
\hline \multirow{2}{*}{ Station } & \multicolumn{6}{|c|}{ Percent } & \multirow{2}{*}{$\begin{array}{l}\text { Modal } \\
\text { size } \\
\text { class } \\
\text { (phi) }\end{array}$} & \multirow[b]{2}{*}{$\begin{array}{l}\mathrm{SC} \\
\text { (phi) }\end{array}$} & \multirow[b]{2}{*}{$\begin{array}{c}\mathrm{SH} \\
\text { (rank) }\end{array}$} & \multirow[t]{2}{*}{ TOC } & \multirow[t]{2}{*}{ TON } \\
\hline & $\begin{array}{c}\text { Silt } \\
\text { and } \\
\text { clay } \\
(\geq 5 \text { phi })\end{array}$ & $\begin{array}{l}\text { Very } \\
\text { fine } \\
\text { sand } \\
\text { (4 phi) }\end{array}$ & $\begin{array}{l}\text { Fine } \\
\text { sand } \\
\text { (3 phi) }\end{array}$ & $\begin{array}{l}\text { Medium } \\
\text { sand } \\
\text { (2 phi) }\end{array}$ & $\begin{array}{l}\text { Coarse } \\
\text { sand } \\
\text { (1 phi) }\end{array}$ & $\begin{array}{l}\text { Gravel } \\
\text { ( } \leq 0 \text { phi) }\end{array}$ & & & & & \\
\hline 59081 & 19.4 & 51.7 & 28.6 & 0.0 & 0.3 & 0.0 & 4.0 & 0.6 & 3 & 3.52 & 0.46 \\
\hline 59108 & 0.0 & 0.0 & 10.0 & 74.5 & 11.9 & 0.0 & 2.0 & 0.5 & 2 & 0.93 & 0.10 \\
\hline 59123 & 13.8 & 28.2 & 53.0 & 4.1 & 0.9 & 0.0 & 3.0 & 0.8 & 4 & 3.43 & 0.47 \\
\hline 59149 & 49.1 & 29.2 & 21.4 & 0.0 & 0.3 & 0.0 & 4.5 & 0.7 & 3 & 9.13 & 1.26 \\
\hline 59150 & 27.1 & 28.5 & 41.5 & 2.5 & 0.5 & 0.0 & 4.0 & 0.8 & 3 & 4.35 & 0.54 \\
\hline 73001 & 64.9 & 19.9 & 7.6 & 6.3 & 1.0 & 0.3 & $\geqslant 5.0$ & 0.7 & 3 & 9.13 & 1.10 \\
\hline 73002 & 32.6 & 4.5 & 19.1 & 32.1 & 11.7 & 0.0 & 3.0 & 1.5 & 5 & 5.48 & 0.69 \\
\hline 73011 & 0.1 & 46.0 & 44.3 & 3.3 & 0.5 & 0.0 & 4.0 & 0.6 & 3 & 3.00 & 0.46 \\
\hline 73018 & 7.7 & 39.3 & 50.3 & 2.1 & 0.6 & 0.0 & 3.0 & 0.6 & 3 & 3.52 & 0.56 \\
\hline 73022 & 1.0 & 0.8 & 10.3 & 65.0 & 23.0 & 0.0 & 3.0 & 0.6 & 3 & 1.09 & 0.08 \\
\hline 73023 & 9.5 & 4.9 & 46.0 & 34.4 & 5.2 & 0.0 & 3.0 & 0.8 & 4 & 3.88 & 0.54 \\
\hline 73024 & 10.0 & 12.5 & 66.1 & 10.2 & 1.0 & 0.3 & 3.0 & 0.7 & 3 & 3.95 & 0.55 \\
\hline 73027 & 7.3 & 6.7 & 67.4 & 16.6 & 2.0 & 0.0 & 3.0 & 0.5 & 2 & 4.48 & 0.70 \\
\hline 73057 & 2.2 & 1.2 & 65.4 & 30.4 & 0.8 & 0.0 & 3.0 & 0.5 & 2 & 1.59 & 0.20 \\
\hline 73058 & 0.5 & 0.3 & 13.9 & 84.7 & 0.6 & 0.0 & 2.0 & 0.3 & 1 & 1.09 & 0.11 \\
\hline 73075 & 4.0 & 28.5 & 57.0 & 8.0 & 2.5 & 0.0 & 3.0 & 0.6 & 3 & 2.16 & 0.33 \\
\hline 73081 & 9.8 & 48.4 & 37.3 & 3.6 & 1.0 & 0.0 & 4.0 & 0.7 & 3 & 3.73 & 0.54 \\
\hline 73104 & 2.0 & 32.5 & 62.9 & 2.5 & 0.1 & 0.0 & 3.0 & 0.5 & 2 & 2.04 & 0.29 \\
\hline 73122 & 7.4 & 43.5 & 45.7 & 3.1 & 0.4 & 0.0 & 4.0 & 0.6 & 3 & 4.27 & 0.65 \\
\hline 74002 & 11.3 & 8.4 & 26.7 & 33.3 & 19.1 & 1.9 & 2.0 & 1.3 & 5 & 5.38 & 0.53 \\
\hline 74009 & 42.9 & 49.0 & 7.3 & 0.5 & 0.2 & 0.0 & 4.0 & 0.5 & 2 & 4.36 & 0.54 \\
\hline 74010 & 35.0 & 50.0 & 10.2 & 3.9 & 0.9 & 0.0 & 4.0 & 0.6 & 3 & 12.10 & 1.98 \\
\hline 74011 & 65.5 & 11.5 & 11.8 & 10.9 & 0.3 & 0.0 & $\geqslant 5.0$ & 0.9 & 4 & 7.16 & 0.89 \\
\hline 74013 & 56.9 & 12.5 & 10.5 & 19.1 & 1.0 & 0.0 & $\geqslant 5.0$ & 1.2 & 5 & 15.01 & 2.13 \\
\hline 74015 & 37.0 & 56.3 & 6.1 & 0.5 & 0.0 & 0.0 & 4.0 & 0.5 & 2 & 5.34 & 0.69 \\
\hline 74020 & 28.4 & 24.3 & 32.9 & 8.5 & 1.5 & 4.4 & 4.0 & 1.0 & 4 & 14.09 & 2.07 \\
\hline 74023 & 45.7 & 25.5 & 17.3 & 10.9 & 0.6 & 0.0 & 4.0 & 1.0 & 4 & 19.35 & 2.78 \\
\hline 74024 & 39.7 & 25.8 & 18.7 & 15.2 & 0.6 & 0.0 & 4.0 & 1.1 & 5 & 15.41 & 2.33 \\
\hline 85061 & 63.8 & 30.1 & 4.9 & 1.2 & 0.0 & 0.0 & $\geqslant 5.0$ & 0.4 & 2 & 7.21 & 1.01 \\
\hline 85064 & 49.2 & 30.8 & 12.4 & 7.4 & 0.2 & 0.0 & 4.0 & 0.8 & 4 & 9.96 & 1.38 \\
\hline 85071 & 50.7 & 21.4 & 19.2 & 8.4 & 0.4 & 0.0 & $\geqslant 5.0$ & 0.9 & 4 & 13.44 & 1.95 \\
\hline 85090 & 57.5 & 18.2 & 10.2 & 13.5 & 0.7 & 0.0 & $\geqslant 5.0$ & 1.0 & 4 & 13.62 & 2.16 \\
\hline 85094 & 9.6 & 10.0 & 25.0 & 22.9 & 21.5 & 11.1 & 2.0 & 1.7 & 5 & 6.40 & 0.93 \\
\hline
\end{tabular}

in the study. Amphipods (Ampeliscidae and Isaeidae) and bivalves (Tellinidae, Nuculidae and Astartidae) dominate the abundance and biomass at these station groups (Table 6). Groups IV and XI are located in the boundary region of the Chirikov Basin in the northern Bering Sea under BSAW. These groups have intermediate abundance (1684 to 2048 ind. $\mathrm{m}^{-2}$ ) and biomass (11.3 to $12.5 \mathrm{~g} \mathrm{C} \mathrm{m}^{-2}$ ) values. These stations are dominated by amphipods (Ampeliscidae), bivalves (Nuculidae and Tellinidae), polychaetes (Nephtyidae), ophiuroids (Ophiuridae and Ophiactidae), and sea urchins (Strongylocentrotidae).

Groups V, VII, VIII, IX and X occur in ACW (Table 5) and show a wide range of abundance (641 to 4193 ind. $\mathrm{m}^{-2}$ ) and biomass (2.0 to $\left.15.4 \mathrm{~g} \mathrm{C} \mathrm{m}^{-2}\right)$. A majority of station groups have low biomass $(2.0$ to $5.3 \mathrm{~g} \mathrm{C}$ $\mathrm{m}^{-2}$ ). The exception is Group VIII (biomass $=15.4 \mathrm{~g} \mathrm{C}$ $\mathrm{m}^{-2}$ ) which is composed of 4 stations that occur in the frontal zone between BSAW and ACW (Fig. 6). The dominant fauna in Groups V, VII, VIII, IX and X are amphipods (Isaeidae, Oediceratidae, Ampeliscidae and Phoxocephalidae), bivalves (Tellinidae, Cardiidae and Thyasiridae), polychaetes (Maldanidae, Sternaspidae and Nephtyidae), echiuroids (Echiuridae), sipunculids (Golfingiidae), ophiuroids (Ophiuridae), sand dollars (Echinarachniidae) and tunicates (Molgulidae and Styelidae; Table 6).

Two Groups (II, VI) are composed of stations located in both BSAW and ACW. Abundance values are in the medium range observed for the area $(1595$ to 2529 ind. $\mathrm{m}^{-2}$ ) as are the biomass values (8.3 to $8.6 \mathrm{~g} \mathrm{C} \mathrm{m} \mathrm{m}^{-2}$; Table 5). Amphipods (Isaeidae, Ampeliscidae and Phoxocephalidae), bivalves (Tellinidae and Nuculidae), polychaetes (Oweniidae and Nephtyidae), echiuroids (Echiuridae), ophiuroids (Ophiuridae) and sand dollars (Echinarachniidae) 


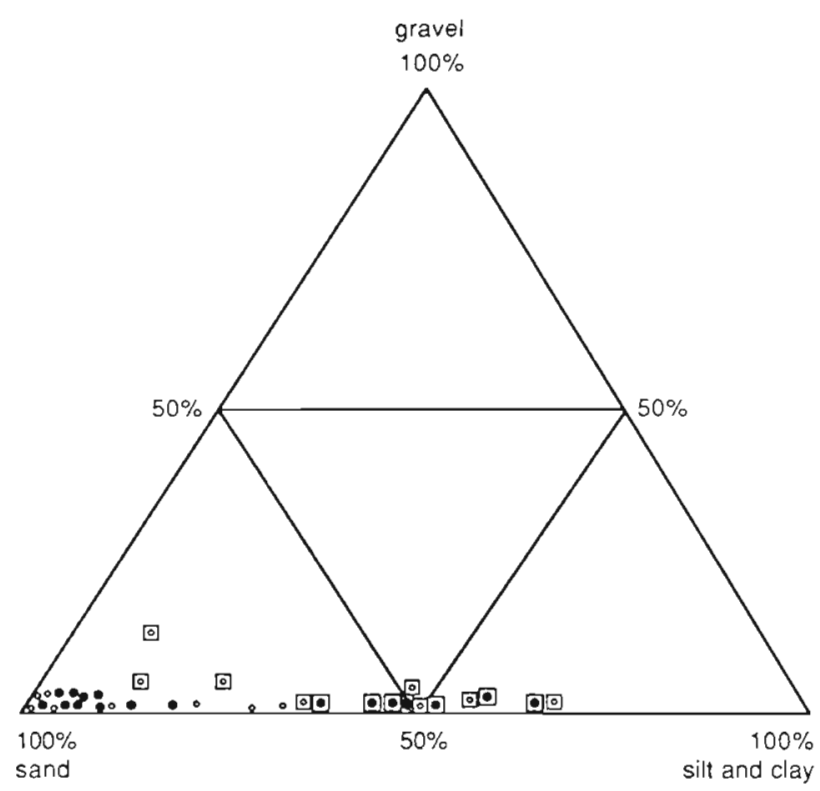

Fig. 4. Ternary diagram for surface sediment grain size class composition. ( $\bullet$ Stations located in Bering Shelf-Anadyr Water; (o) stations in Alaska Coastal Water; Boxed: stations located in the Chukchi Sea; unboxed: those in the Bering Sea

were dominant fauna at these 2 station groups (Table 6).

\section{Feeding groups}

Selective detritus- and suspension-feeding fauna (primarily amphipods and bivalves) dominate the faunal abundance at a majority of station groups in the region (Table 7). Deposit-feeding polychaetes and/or bivalves are also dominant fauna in station groups where silt and clay content ranged from 16 to $52 \%$ (excluding Group X; Tables 5 and 7).

\section{Diversity}

Diversity $\left(H^{\prime}\right)$ and evenness $(J)$ are positively correlated with each other $(r=0.900, p<0.01, n=49)$. Thus, while the following discussion outlines the environmental variables correlated to diversity $\left(\mathrm{H}^{\prime}\right)$ only, the results are the same for evenness (Table 8). Sediment sorting, and consequently sediment heterogeneity, is better correlated than any other variable to faunal diversity at all stations. Stations located in high percent silt and clay sediments are positively correlated to diversity, while stations in high percent fine sand are negatively correlated with diversity. Surface sediment TOC and TON are positively correlated to diversity. The 2 water column variables that correlate to benthic faunal diversity are bottom temperature (positively) and bottom chlorophyll a (negatively).

BSAW and ACW stations clearly show a positive relation between diversity and sediment sorting, an indicator of sediment heterogeneity (Fig. 7). Diversity is more highly correlated with sediment sorting at stations in BSAW than with stations in ACW, although both are significant $(p<0.05)$. Benthic faunal diversity is more variable in well-sorted, homogeneous sediments in ACW than in BSAW. In more poorly-sorted, heterogeneous sediments, diversity data for both water types had a better fit to the regression line (Fig. 7). In addition, stations located in the Chukchi Sea have the highest diversity indices, and while heterogeneous sediments characterize BSAW, a wide variety of sediment composition occur in $\mathrm{ACW}$.

The Shannon-Weaver indices $\left(H^{\prime}\right.$ and $J$ ) are lowest for BSAW station groups $\left(H^{\prime}=1.06\right.$ to $2.65, J=0.33$ to $0.66)$ and highest for ACW station groups $\left(H^{\prime}=1.75\right.$ to 3.57, $J=0.50$ to 0.84 ; Table 5). This trend can be

Table 3. Pearson product-moment correlation statistics between sediment total organic carbon and total organic nitrogen and sediment composition, sorting and heterogeneity at all benthic stations $(n=33)$. $r$ : correlation coefficient; $p$ : level of significance; ns: no significance

\begin{tabular}{|c|c|c|c|c|}
\hline \multirow[t]{2}{*}{$\begin{array}{l}\text { Surface } \\
\text { sediment } \\
\text { composition }\end{array}$} & \multicolumn{4}{|c|}{ Sediment parameter } \\
\hline & $r$ & $p$ & $r$ & $p$ \\
\hline$\%$ Silt and clay & 0.772 & $<0.01$ & 0.673 & $<0.01$ \\
\hline$\%$ Very fine sand & 0.096 & ns & 0.107 & ns \\
\hline$\%$ Fine sand & -0.485 & $<0.01$ & -0.403 & $0.01<p<0.05$ \\
\hline$\%$ Medium sand & -0.336 & ns & -0.320 & ns \\
\hline$\%$ Coarse sand & -0.261 & ns & -0.270 & ns \\
\hline$\%$ Gravel & 0.107 & ns & 0.121 & ns \\
\hline Sediment sorting & 0.394 & $0.01<p<0.05$ & 0.468 & $<0.01$ \\
\hline $\begin{array}{l}\text { Sediment } \\
\text { heterogeneity }\end{array}$ & 0.445 & $0.01<p<0.05$ & 0.524 & $<0.01$ \\
\hline
\end{tabular}




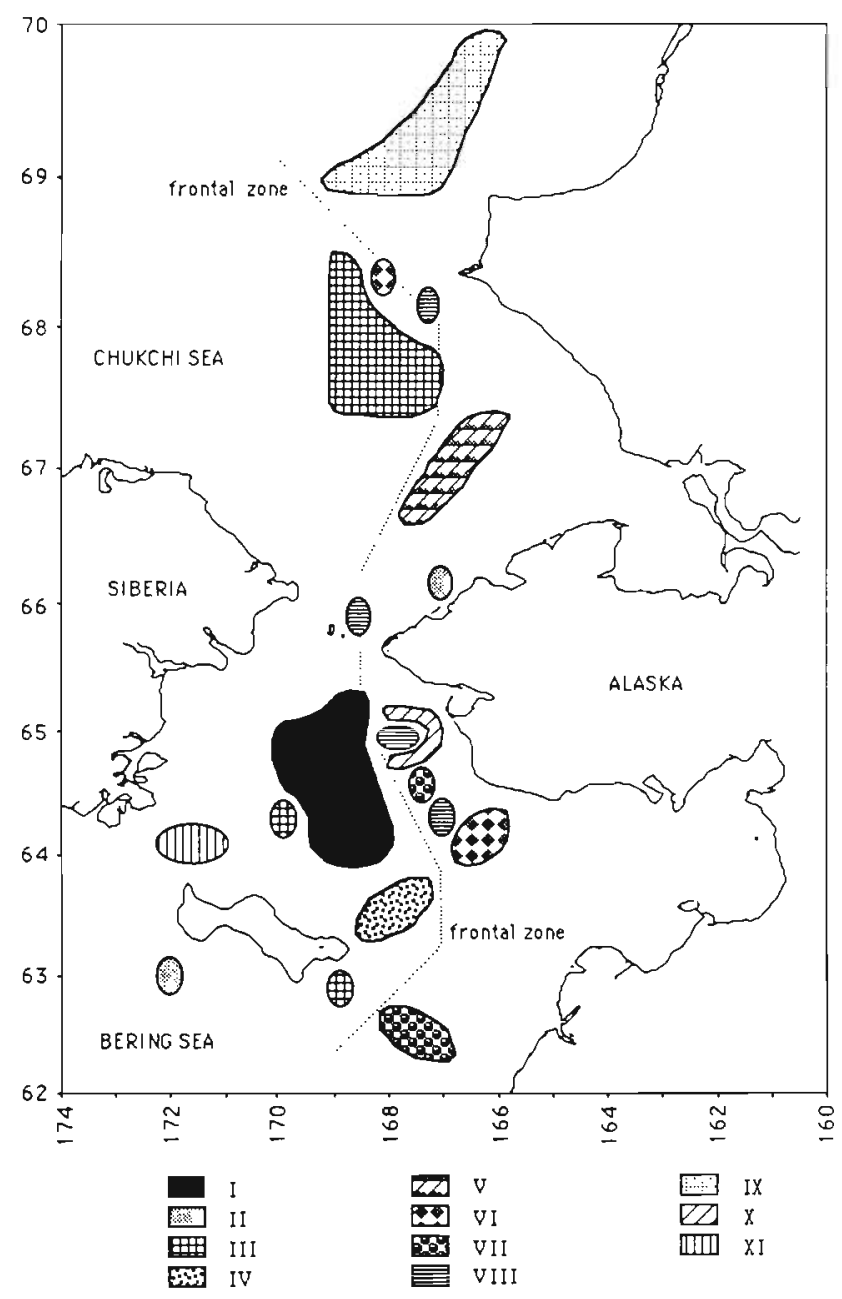

Fig. 6. Distribution of faunal communities based on cluster group analysis (see Table 6 for list of dominant fauna) more structural heterogeneity hypothesized to provide increased niche space and higher diversity (Gray 1981). In addition, grain size and sediment sorting are characteristics of specific hydrographic regimes, with coarse sediments indicative of high current and wave action compared to silt and clay sediments that indicate reduced currents (Gray 1981, Weston 1988). Sediment structure can describe the local environment and influence the biological pressures (i.e. habitat selection for settlement, food resource type and availability) that benthic fauna experience in a sedimentary habitat (Sanders et al.. 1962, Butman 1987, Riddle 1988),

In our study, benthic faunal diversity is highly correlated $(p<0.01)$ with 5 sediment parameters: sediment sorting and heterogeneity, percent silt and clay, TOC and TON, with diversity correlated with percent fine sand at a lower significance level $(0.01<p<0.05)$. TOC and TON are positively correlated with percent silt and clay and sediment heterogeneity, and negatively with percent fine sand. This is consistent with our hypothesis that benthic diversity should be higher in the Chukchi Sea (higher silt and clay content, more heterogeneous sediments) than the northern Bering Sea (higher sand content, more homogeneous sediments; Figs. 7 and 8).

An example of the relation between changes in sediment heterogeneity and faunal diversity can be demonstrated for faunal groups in BSAW. Station Group I, in the central Chirikov Basin, characterized by moderately homogeneous, sandy sediments, has a low diversity of 1.38 (Table 5). By comparison, stations located in increasingly heterogeneous sediments should show higher diversities. This can be demonstrated in Station Group III in the southern Chukchi Sea, characterized by more heterogeneous, very fine

Table 5. Mean benthic abundance, biomass, diversity $\left(H^{\prime}\right)$, evenness $(J)$, sediment heterogeneity (SH), and sediment composition for benthic station groups located in Bering Shelf-Anadyr Water (BSAW) and Alaska Coastal Water (ACW)

\begin{tabular}{|c|c|c|c|c|c|c|c|c|c|c|c|c|}
\hline \multirow[t]{2}{*}{ Group } & \multirow{2}{*}{$\begin{array}{l}\text { Water } \\
\text { type }\end{array}$} & \multirow{2}{*}{$\begin{array}{c}\text { Mean } \\
\text { abundance } \\
\text { (ind. } \mathrm{m}^{-2} \text { ) }\end{array}$} & \multirow[b]{2}{*}{$\begin{array}{c}\text { Mean } \\
\text { biomass } \\
\left(\mathrm{g} \mathrm{C} \mathrm{m}^{-2}\right)\end{array}$} & \multirow[t]{2}{*}{$H^{\prime}$} & \multirow[t]{2}{*}{$J$} & \multirow[b]{2}{*}{$\begin{array}{c}\mathrm{SH} \\
\text { (rank) }\end{array}$} & \multicolumn{6}{|c|}{ Sediment composition (\%) } \\
\hline & & & & & & & $\begin{array}{l}\text { Silt } \\
\text { and } \\
\text { clay }\end{array}$ & $\begin{array}{l}\text { Very } \\
\text { fine } \\
\text { sand }\end{array}$ & $\begin{array}{l}\text { Fine } \\
\text { sand }\end{array}$ & $\begin{array}{l}\text { Med. } \\
\text { sand }\end{array}$ & $\begin{array}{c}\text { Coarse } \\
\text { sand }\end{array}$ & Gravel \\
\hline I & BSAW & 6940 & 22.2 & 1.38 & 0.34 & 3 & 6.9 & 31.7 & 53.8 & 5.9 & 1.0 & 0.0 \\
\hline II & Both & 2529 & 8.3 & 2.51 & 0.67 & - & - & - & - & - & - & - \\
\hline III & BSAW & 5365 & 24.2 & 2.65 & 0.66 & 4 & 50.9 & 25.3 & 13.7 & 9.5 & 0.6 & 0.0 \\
\hline IV & BSAW & 2048 & 11.3 & 1.73 & 0.55 & 3 & 34.3 & 40.5 & 25.0 & 0.0 & 0.3 & 0.0 \\
\hline $\mathrm{v}$ & $\mathrm{ACW}$ & 1947 & 4.6 & 2.86 & 0.75 & 3 & 52.0 & 36.6 & 8.2 & 3.0 & 0.1 & 0.0 \\
\hline VI & Both & 1595 & 8.6 & 3.14 & 0.79 & 4 & 43.9 & 24.7 & 22.6 & 8.0 & 0.7 & 0.1 \\
\hline VII & $\mathrm{ACW}$ & 4193 & 5.3 & 2.25 & 0.56 & 1 & 0.5 & 0.3 & 13.9 & 84.7 & 0.6 & 0.0 \\
\hline VIII & $\mathrm{ACW}$ & 1367 & 15.4 & 3.57 & 0.84 & 5 & 15.8 & 7.0 & 29.2 & 30.7 & 14.4 & 3.3 \\
\hline IX & $\mathrm{ACW}$ & 641 & 4.3 & 2.68 & 0.78 & 4 & 40.8 & 31.0 & 16.5 & 9.4 & 0.8 & 1.5 \\
\hline $\mathrm{x}$ & $\mathrm{ACW}$ & 718 & 2.0 & 1.75 & 0.50 & 2 & 1.1 & 0.7 & 28.6 & 56.7 & 11.9 & 0.0 \\
\hline $\mathrm{XI}$ & BSAW & 1684 & 12.5 & 1.06 & 0.33 & - & - & - & - & - & - & - \\
\hline
\end{tabular}


Table 6. Dominant benthic fauna by percent abundance and biomass occurring in station Groups I to XI in Bering Shelf-Anadyr Water (BSAW) and Alaska Coastal Water (ACW). Mean abundance and biomass values for station groups are listed in Table 5

\begin{tabular}{|c|c|c|c|c|c|}
\hline $\begin{array}{l}\text { Station } \\
\text { Group }\end{array}$ & Water type & $\begin{array}{l}\text { Dominant family } \\
\text { by } \% \text { abundance }\end{array}$ & $\begin{array}{c}\% \\
\text { abundance }\end{array}$ & $\begin{array}{l}\text { Dominant family } \\
\text { by } \% \text { biomass }\end{array}$ & $\begin{array}{c}\% \\
\text { biomass }\end{array}$ \\
\hline I & BSAW & $\begin{array}{l}\text { Ampeliscidae } \\
\text { Isaeidae } \\
\text { Phoxocephalidae }\end{array}$ & $\begin{array}{r}70 \\
11 \\
4\end{array}$ & $\begin{array}{l}\text { Ampeliscidae } \\
\text { Tellinidae } \\
\text { Astartidae }\end{array}$ & $\begin{array}{l}36 \\
23 \\
15\end{array}$ \\
\hline II & Both & $\begin{array}{l}\text { Oweniidae } \\
\text { Isaeidae } \\
\text { Ampeliscidae }\end{array}$ & $\begin{array}{r}34 \\
10 \\
9\end{array}$ & $\begin{array}{l}\text { Tellinidae } \\
\text { Ophiuridae } \\
\text { Sternaspidae }\end{array}$ & $\begin{array}{r}65 \\
6 \\
4\end{array}$ \\
\hline III & BSAW & $\begin{array}{l}\text { Ampeliscidae } \\
\text { Isaeidae } \\
\text { Nuculidae }\end{array}$ & $\begin{array}{l}21 \\
16 \\
13\end{array}$ & $\begin{array}{l}\text { Tellinidae } \\
\text { Nuculidae } \\
\text { Ampeliscidae }\end{array}$ & $\begin{array}{r}32 \\
25 \\
9\end{array}$ \\
\hline IV & BSAW & $\begin{array}{l}\text { Nuculidae } \\
\text { Tellinidae } \\
\text { Ampeliscidae }\end{array}$ & $\begin{array}{l}54 \\
13 \\
11\end{array}$ & $\begin{array}{l}\text { Tellinidae } \\
\text { Nuculidae } \\
\text { Ampeliscidae }\end{array}$ & $\begin{array}{r}36 \\
22 \\
9\end{array}$ \\
\hline V & $\mathrm{ACW}$ & $\begin{array}{l}\text { Tellinidae } \\
\text { Thyasiridae } \\
\text { Styelidae }\end{array}$ & $\begin{array}{l}1.3 \\
10 \\
10\end{array}$ & $\begin{array}{l}\text { Styelidae } \\
\text { Cardiidae } \\
\text { Sternaspidae }\end{array}$ & $\begin{array}{l}48 \\
12 \\
12\end{array}$ \\
\hline VI & Both & $\begin{array}{l}\text { Echiuridae } \\
\text { Nuculidae } \\
\text { Phoxocephalidae }\end{array}$ & $\begin{array}{r}12 \\
12 \\
7\end{array}$ & $\begin{array}{l}\text { Nephtyidae } \\
\text { Echinarachniidae } \\
\text { Nuculidae }\end{array}$ & $\begin{array}{l}23 \\
18 \\
14\end{array}$ \\
\hline VII & $\mathrm{ACW}$ & $\begin{array}{l}\text { Isaeidae } \\
\text { Oediceratidae } \\
\text { Echiuridae }\end{array}$ & $\begin{array}{r}46 \\
8 \\
8\end{array}$ & $\begin{array}{l}\text { Echinarachniidae } \\
\text { Cardiidae } \\
\text { Nephtyidae }\end{array}$ & $\begin{array}{r}48 \\
17 \\
7\end{array}$ \\
\hline VIII & $\mathrm{ACW}$ & $\begin{array}{l}\text { Ampeliscidae } \\
\text { Phoxocephalidae } \\
\text { Isaeidae }\end{array}$ & $\begin{array}{l}9 \\
7 \\
7\end{array}$ & $\begin{array}{l}\text { Molgulidae } \\
\text { Nephtyidae } \\
\text { Ampharetidae }\end{array}$ & $\begin{array}{r}52 \\
10 \\
9\end{array}$ \\
\hline$I X$ & $\mathrm{ACW}$ & $\begin{array}{l}\text { Maldanidae } \\
\text { Ophiuridae } \\
\text { Ampeliscidae }\end{array}$ & $\begin{array}{l}15 \\
15 \\
13\end{array}$ & $\begin{array}{l}\text { Golfingiidae } \\
\text { Nephtyidae } \\
\text { Maldanidae }\end{array}$ & $\begin{array}{l}25 \\
20 \\
16\end{array}$ \\
\hline$x$ & $\mathrm{ACW}$ & $\begin{array}{l}\text { Isaeidae } \\
\text { Echinarachniidae } \\
\text { Nuculidae }\end{array}$ & $\begin{array}{r}56 \\
17 \\
5\end{array}$ & $\begin{array}{l}\text { Tellinidae } \\
\text { Nephtyidae } \\
\text { Veneridae }\end{array}$ & $\begin{array}{l}31 \\
20 \\
10\end{array}$ \\
\hline XI & BSAW & $\begin{array}{l}\text { Ophiuridae } \\
\text { Ophiactidae } \\
\text { Strongylocentrotidae }\end{array}$ & $\begin{array}{r}76 \\
10 \\
4\end{array}$ & $\begin{array}{l}\text { Strongylocentrotidae } \\
\text { Nephtyidae } \\
\text { Alyconacea } \\
\text { Neptheidae }\end{array}$ & $\begin{array}{l}34 \\
15 \\
11\end{array}$ \\
\hline
\end{tabular}

sand/silt and clay sediments, with a higher diversity of 2.65. In addition, although the most common fauna, which are selective detritus/suspension feeders, are similar for both station groups, there is a noticeable change in percent faunal dominance by abundance between the groups. Ampeliscid amphipods dominate $70 \%$ of the abundance in Station Group I, dropping to only $21 \%$ of the abundance in Station Group III (Table 7). Bivalves compose less than $5 \%$ of the abundance in Group I, yet make up $13 \%$ of the abundance in Group III.

In another comparison, station groups in ACW, such as Groups V and $\mathrm{X}$, which are dominated by selective detritus/suspension feeders, show lower diversities in more homogeneous, medium sand sediments ( $\mathrm{X}$, $\left.H^{\prime}=1.75\right)$, compared to higher diversities in more heterogeneous, silt and clay sediments (V, $H^{\prime}=2.86$; Table 5). No station groups in ACW have similar fauna with which to compare faunal composition changes as with Station Groups I and III in BSAW Nevertheless, the combined data for both BSAW and ACW support the conclusion that sediment grain size composition has a direct influence on faunal diversity (Fig. 7). However, faunal diversity within homogeneous sediments in both ACW and BSAW is not uniformly similar, indicating that additional factors influence benthic community structure.

\section{Food supply}

Sediment structure can be considered an indicator of food availability, which is influenced by hydrographic 
Table 7. Dominant fauna and percent abundance occurring in feeding categories for station groups in the northern Bering and Chukchi Seas. Dominant fauna are those families that compose $\geq 5 \%$ of the total station abundance. Feeding modes are based on descriptions by Stoker (1978), Fauchald \& Jumars (1979), Barnes (1980), and Feder at al. (1985)

\begin{tabular}{|c|c|c|c|c|c|c|c|c|}
\hline $\begin{array}{l}\text { Station } \\
\text { Group }\end{array}$ & $\begin{array}{l}\text { Selective } \\
\text { detritus }\end{array}$ & $(\%)$ & Deposit & $(\%)$ & Suspension & $(\%)$ & $\begin{array}{l}\text { Selective detritus/ } \\
\text { suspension }\end{array}$ & $(\%)$ \\
\hline I & Isaeidae & 11 & & & & & Ampeliscidae & 70 \\
\hline II & $\begin{array}{l}\text { Leuconidae } \\
\text { Isaeidae }\end{array}$ & $\begin{array}{r}5 \\
10\end{array}$ & Orbiniidae & 6 & Alcyoniididae & 8 & $\begin{array}{l}\text { Oweniidae } \\
\text { Ampeliscidae }\end{array}$ & $\begin{array}{r}34 \\
9\end{array}$ \\
\hline III & $\begin{array}{l}\text { Isaeidae } \\
\text { Nuculidae } \\
\text { Phoxocephalidae } \\
\text { Haustoriidae } \\
\text { Leuconidae }\end{array}$ & $\begin{array}{c}6 \\
13 \\
9 \\
7 \\
6\end{array}$ & & & & & Ampeliscidae & 21 \\
\hline IV & $\begin{array}{l}\text { Nuculidae } \\
\text { Isaeidae }\end{array}$ & $\begin{array}{r}54 \\
5\end{array}$ & & & & & $\begin{array}{l}\text { Tellinidae } \\
\text { Ampeliscidae }\end{array}$ & $\begin{array}{l}13 \\
11\end{array}$ \\
\hline V & $\begin{array}{l}\text { Phoxocephalidae } \\
\text { Oediceratidae } \\
\text { Nuculidae } \\
\text { Leuconidae }\end{array}$ & $\begin{array}{r}10 \\
10 \\
10 \\
6\end{array}$ & & & $\begin{array}{l}\text { Thyasiridae } \\
\text { Styelidae }\end{array}$ & $\begin{array}{l}10 \\
10\end{array}$ & Tellinidae & 14 \\
\hline VI & $\begin{array}{l}\text { Echiuridae } \\
\text { Nuculidae } \\
\text { Phoxocephalidae } \\
\text { Cirratulidae }\end{array}$ & $\begin{array}{r}12 \\
12 \\
7 \\
6\end{array}$ & $\begin{array}{l}\text { Capitellidae } \\
\text { Sternaspidae } \\
\text { Maldanidae }\end{array}$ & $\begin{array}{l}6 \\
6 \\
5\end{array}$ & & & $\begin{array}{l}\text { Amphiuridae } \\
\text { Echinarachniidae }\end{array}$ & $\begin{array}{l}6 \\
5\end{array}$ \\
\hline VII & $\begin{array}{l}\text { Isaeidae } \\
\text { Oediceratidae } \\
\text { Echiuridae } \\
\text { Ampharetidae } \\
\text { Phoxocephalidae }\end{array}$ & $\begin{array}{r}46 \\
8 \\
8 \\
6 \\
5\end{array}$ & & & & & & \\
\hline VIII & $\begin{array}{l}\text { Phoxocephalidae } \\
\text { Isaeidae } \\
\text { Leuconidae }\end{array}$ & $\begin{array}{l}7 \\
7 \\
5\end{array}$ & Orbiniidae & 5 & & & $\begin{array}{l}\text { Ampeliscidae } \\
\text { Corophidae }\end{array}$ & $\begin{array}{l}9 \\
5\end{array}$ \\
\hline IX & $\begin{array}{l}\text { Nuculidae } \\
\text { Leuconidae }\end{array}$ & $\begin{array}{l}11 \\
10\end{array}$ & $\begin{array}{l}\text { Maldanidae } \\
\text { Capitellidae }\end{array}$ & $\begin{array}{r}15 \\
5\end{array}$ & & & $\begin{array}{l}\text { Ophiuridae } \\
\text { Ampeliscidae }\end{array}$ & $\begin{array}{l}15 \\
13\end{array}$ \\
\hline $\mathrm{x}$ & $\begin{array}{l}\text { Isaeidae } \\
\text { Nuculidae }^{a}\end{array}$ & $\begin{array}{r}56 \\
5\end{array}$ & & & & & Echinarachniidae & 17 \\
\hline$X I$ & & & & & & & $\begin{array}{l}\text { Ophiuridae } \\
\text { Ophiactidae }\end{array}$ & $\begin{array}{l}76 \\
10\end{array}$ \\
\hline
\end{tabular}

regimes, and these factors combine to influence animal feeding strategies (Sanders et al. 1962). It has been hypothesized that faunal diversities will be low at low food resource conditions due to limiting resources (Valiela 1984). The positive correlations of sediment TOC and silt and clay content (which are also correlated to each other) with diversity indicates that low food supply is related to low faunal diversity and that as surface sediment TOC and silt and clay content increases in the Chukchi Sea, so does faunal diversity. However, it has also been hypothesized (Valiela 1984) that faunal diversity will be low at high resource conditions, when a few animals would dominate a community. In this study, bottom water chlorophyll $a$ is negatively corre- lated to benthic diversity, indicating that higher food availability in the bottom water of BSAW may have a negative influence on diversity.

As a result, this high resource availability negatively affecting diversity may be acting in concert with homogeneous sediment composition in the central Chirikov Basin in Station Group 1, where selective detritus/suspension-feeding ampeliscid amphipods dominate both in abundance and biomass (as described above). Blackburn (1987) proposed that in the northern Bering Sea under BSAW, the microbial component of carbon degradation is displaced by direct macrofaunal feeding by high amphipod populations, resulting in low organic carbon accumulation in spite of 

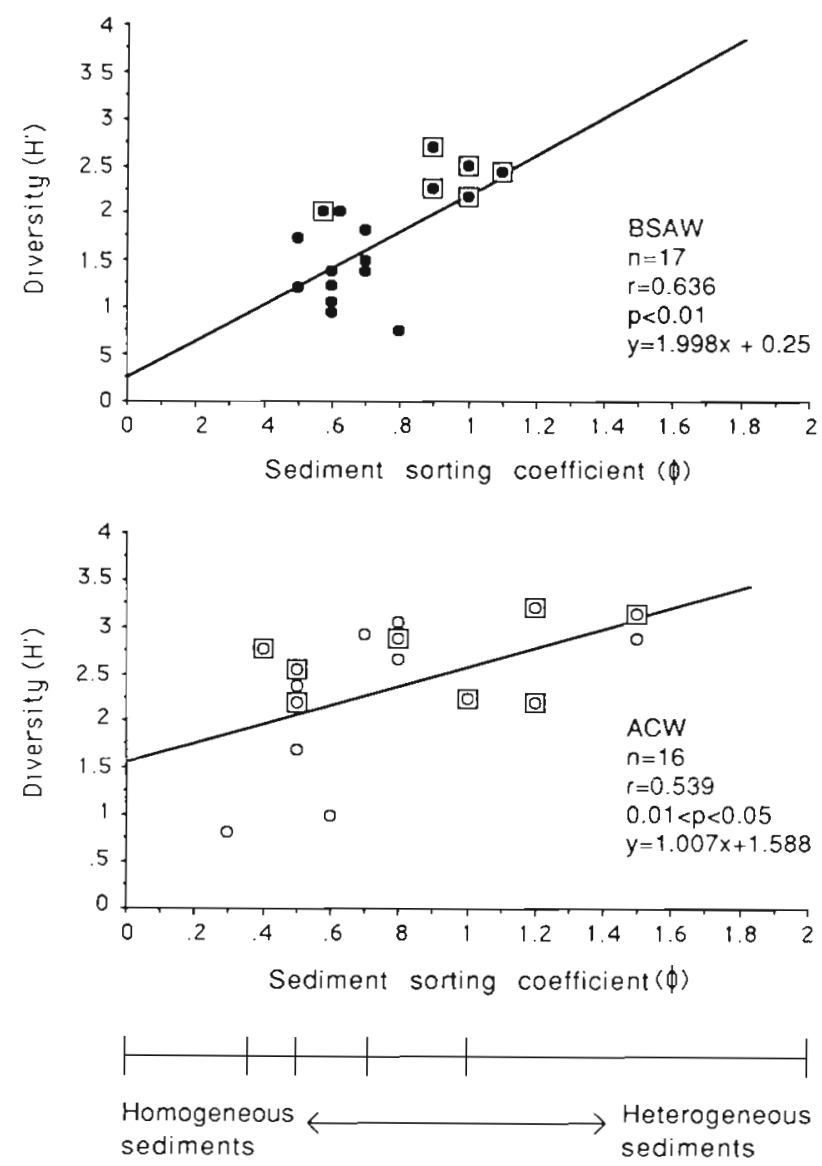

Fig. 7 Relation between benthic faunal diversity and sediment sorting (as an indicator of sediment heterogeneity) for stations in Bering Shelf-Anadyr Water (upper graph) and Alaska Coastal Water (lower graph). Boxed: stations located in the Chukchi Sea; unboxed: those in the Bering Sea

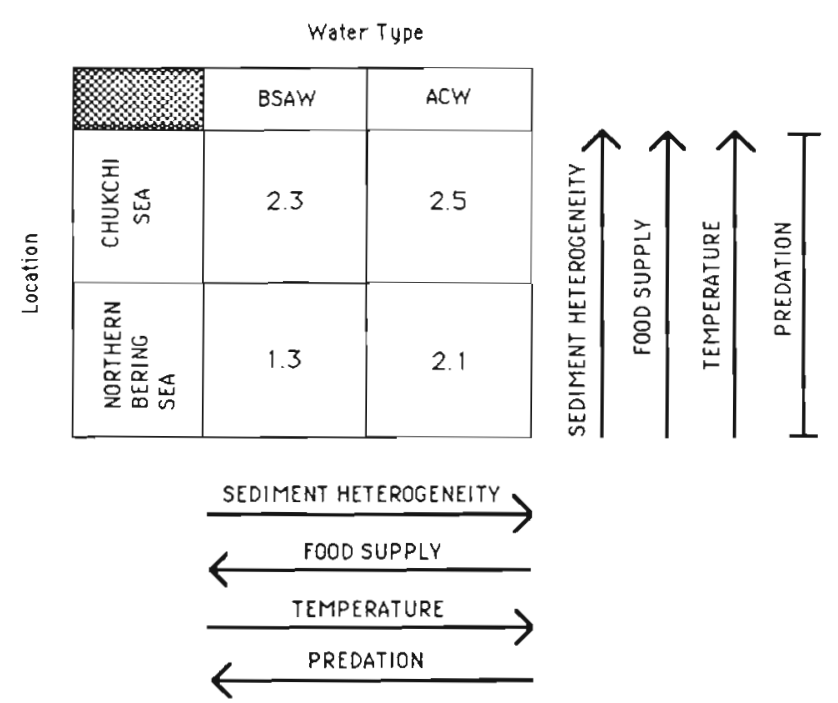

Fig. 8. Average benthic diversity for stations located in the northern Bering and Chukchi Seas in each water type. Arrows indicate our study results for factors influencing diversity; solid predation line indicates an estimated constant value

high organic carbon supply to the benthos. By contrast, Station Group III in the Chukchi Sea, also in a region thought to have a high particulate organic carbon flux to the benthos (Grebmeier 1987), but where organic carbon accumulates and more heterogeneous sediments occur, has higher diversity of selective detritus/ suspension-feeding fauna. In addition, sediments with medium to high silt and clay content in the Bering and Chukchi Seas have an increased number of depositfeeding animals (Table 7 ), suggesting both food supply

Table 8. Pearson product-moment correlation matrix between environmental variables and benthic faunal diversity $\left(H^{\prime}\right)$ and evenness $(J)$ for all stations. $r$ correlation coefficient; $p$ : level of significance

\begin{tabular}{|c|c|c|c|c|c|}
\hline \multirow{2}{*}{$\begin{array}{l}\text { Environmental } \\
\text { variable }\end{array}$} & \multirow{2}{*}{$\begin{array}{l}\text { Number of } \\
\text { stations }\end{array}$} & \multicolumn{2}{|c|}{ Diversity $\left(H^{\prime}\right)$} & \multicolumn{2}{|c|}{ Evenness $(J)$} \\
\hline & & $r$ & $p$ & $r$ & $p$ \\
\hline Sediment sorting & 33 & 0.540 & $<0.01$ & 0.462 & $<0.01$ \\
\hline Sediment heterogeneity & 33 & 0.461 & $<0.01$ & 0.390 & $<0.01$ \\
\hline Percent silt and clay & 33 & 0.521 & $<0.01$ & 0.543 & $<0.01$ \\
\hline Sediment TOC & 38 & 0.491 & $<0.01$ & 0.451 & $<0.01$ \\
\hline Bottom water temp. & 46 & 0.440 & $<0.01$ & 0.415 & $<0.01$ \\
\hline Sediment TON & 38 & 0.416 & $<0.01$ & 0.385 & $0.01<p<0.05$ \\
\hline Percent fine sand & 33 & -0.383 & $0.01<p<0.05$ & -0.417 & $0.01<p<0.05$ \\
\hline Bottom water chl a & 47 & -0.305 & $0.01<p<0.05$ & -0.297 & $0.01<p<0.05$ \\
\hline Percent gravel & 33 & 0.318 & ns & 0.289 & ns \\
\hline Integrated chl a & 34 & -0.290 & ns & -0.309 & ns \\
\hline Bottom water sigma t & 45 & -0.267 & ns & -0.238 & ns \\
\hline Modal sedıment grain sıze & 33 & 0.225 & ns & 0.293 & ns \\
\hline Bottom water salinity & 45 & -0.207 & ns & -0.156 & ns \\
\hline Percent coarse sand & 33 & 0.184 & ns & 0.109 & ns \\
\hline Percent very fine sand & 33 & -0.164 & ns & -0.109 & ns \\
\hline Percent medium sand & 33 & -0.119 & ns & -0.130 & ns \\
\hline Depth & 49 & -0.008 & ns & -0.082 & ns \\
\hline
\end{tabular}


Table 9. Categories for Shannon-Weaver information index for diversity $\left(H^{\prime}\right)$ and the percentage of all benthic stations $(n=49)$ in each water type

\begin{tabular}{|c|c|c|c|}
\hline \multirow{2}{*}{$\begin{array}{c}\text { Shamnon-Weaver } \\
\text { information index } \\
H^{\prime}\end{array}$} & \multirow[t]{2}{*}{ Diversity } & \multicolumn{2}{|c|}{$\begin{array}{l}\text { Percentage of all stations } \\
\text { in each water type }\end{array}$} \\
\hline & & Bering Shelf-Anadyr Water & Alaska Coastal Water \\
\hline $0.5-1.4$ & Low & 31 & 6 \\
\hline $1.5-2.4$ & Medium & 20 & 14 \\
\hline $2.5-3.4$ & High & 9 & 22 \\
\hline
\end{tabular}

and sediment structure influence the higher diversities observed.

Since food is relatively unlimited in BSAW during the summer, sediment heterogeneity must be the major factor affecting benthic diversity in offshore waters of the Chukchi Sea (Fig, 8). Food supply, nevertheless, influences benthic biomass (Grebmeier 1987, Grebmeier et al. 1988). We compared biomass for the dominant station groups under BSAW and observed similar values, $22.2 \mathrm{~g} \mathrm{C} \mathrm{m}^{-2}$ for Group I (northern Bering Sea) and $24.2 \mathrm{~g} \mathrm{C} \mathrm{m}^{-2}$ for Group III (southern Chukchi Sea; Table 5). However, a more detailed analysis of individual stations in these groups shows a northerly maximum in benthic biomass in the Chukchi Sea (Group III, Station 74010, biomass $=59.0 \mathrm{~g} \mathrm{C} \mathrm{m}^{-2}, H^{\prime}=2.00$ ), which is almost twice the value for the highest biomass station in Group I (Station 59120, biomass $=32.2 \mathrm{~g} \mathrm{C}$ $\mathrm{m}^{-2}, H^{\prime}=0.89$; Table 1). Surface sediment TOC is positively correlated to percent silt and clay and sediment heterogeneity, both of which increase in the Chukchi Sea sediments, which then influences both community structure and benthic biomass.

By comparison, food supply is limited in ACW but variability in benthic diversity occurs. Benthic faunal diversities are highest in the Chukchi Sea, where sediment TOC is highest, although sediment heterogeneity is variable (Fig. 7). In addition, faunal diversity is most variable in homogeneous sediments in ACW. Based upon our data from this subarctic system, we propose that in food-limited systems, especially in homogeneous sediments, food supply will be increasingly important in regulating faunal diversity.

\section{Environmental stability}

Environmental stability is defined by constant environmental variables, such as temperature, salinity and oxygen. Although relatively constant temperature, salinity, oxygen and primary production can occur within each water type seasonally during the summer, this shallow system is disturbed by frequent storms and variable transport conditions which influence hydro- graphic and biological conditions throughout the openwater period (Walsh et al. 1987). The front which develops during the ice-free period fluctuates seasonally, emphasizing the dynamic nature of this region.

Faunal diversities are lowest at stations in BSAW and highest at stations in $\mathrm{ACW}$, indicating a relation between water type characteristics and benthic diversity (Table 9). Of all the water column variables we measured, summer bottom water temperature showed the highest positive correlation with faunal diversity. Bottom water temperatures are higher seasonally in $\mathrm{ACW}\left(>+2^{\circ} \mathrm{C}\right)$, where faunal diversity is highest, compared to BSAW $\left(-1\right.$ to $\left.+2{ }^{\circ} \mathrm{C}\right)$, where faunal diversity is lowest (Figs. 7 and 8; Coachman 1987). In addition, summer bottom water temperatures in the Chukchi Sea are warmer $\left(2\right.$ to $\left.9^{\circ} \mathrm{C}\right)$ for both BSAW and ACW, corresponding to increased benthic diversity, than average bottom water temperatures in the northern Bering Sea $\left(-1\right.$ to $\left.+3^{\circ} \mathrm{C}\right)$ where diversity is lower (Figs. 7 and 8 ; Coachman 1987).

\section{Predation}

Predation crops the prey population, often lowering competiton among species that would otherwise exclude each other, and thus allow more species to occupy the same region (Valiela 1984). However, in some soft bottom communities where predation is less effective, such as estuaries and lagoons, evidence suggests that reduced epifaunal predation allows increased benthic diversity (Peterson 1979). Predators can also act as disturbance agents on soft-bottom communities and influence community structure (Gray 1981). Thus, predators can reduce faunal abundance both by direct consumption and through mortality caused by activities that disturb benthic communities (Kneib 1985, Palmer 1988).

Marine mammals are important predators on sediment-dwelling benthic fauna on the Bering/Chukchi shelf and appear to both positively and negatively influence diversity. Approximately 15000 gray whales Eschrichtius robustus, which feed primarily on 
amphipods, and 200000 Pacific walrus Odobenus rosmarus, which feed primarily on bivalves, migrate seasonally through the area (Fay et al. 1984, Nerini 1984). Both gray whales and walruses disturb the sediments during feeding activities, creating temporal and spatial patches which would theoretically increase benthic diversity and possibly enhance secondary productivity through sediment reworking (Oliver at al. 1983a, b, Valiela 1984, Oliver \& Slattery 1985). During feeding, gray whales increase erosion of fine-grained sediments, as well as open up space for recolonization, and thus influence successional processes (Oliver \& Slattery 1985, Nelson \& Johnson 1987). Their feeding activity has been proposed to be one reason for the variability in benthic faunal distribution measured in the region (Stoker 1981).

Ampeliscid amphipod communities, which dominate high biomass regions in this study, are characterized by low to medium faunal diversity. The major feeding areas for gray whales and walruses are in the high benthic biomass areas of the Chirikov Basin and Chukchi Sea (Fay et al. 1977, 1984, Nelson \& Johnson 1987). Thus, the predation hypothesis of increased diversity in regions of high predation is not consistent with patterns we observed in the Chirikov Basin. Although patch formation occurs, the faster currents in the region transport finer sediments northward to the Chukchi Sea (Nelson \& Johnson 1987), thus reducing sediment heterogeneity. However, it is possible in the southern Chukchi Sea, where diversity is higher, that marine mammal feeding activities increase the structural heterogeneity of the environment and that the reduced currents in the region allow a more heterogeneous sediment regime to occur, thus influencing diversity. Overall, the seasonal occurrence of large populations of benthic-feeding marine mammals in these waters necessitates the presence of a productive and reliable invertebrate food source.

Epifaunal predation is estimated to be an order of magnitude lower than marine mammal predation in the study area (Grebmeier 1987). Furthermore, fish predation on benthic animals is believed reduced due to extremely low temperatures (Neiman 1963, Jewett \& Feder 1980), and this probably reduces its influence on benthic community structure in the area (Jewett \& Feder 1981).

\section{Benthic community stability}

Faunal groupings characterized by Stoker (1978) correspond in general location and composition to those station cluster groupings found in this study (Fig. 6). In a more detailed study, Grebmeier (1987) found no major change in faunal structure between these faunal groups and those determined by Stoker over $10 \mathrm{yr}$ earlier. In addition, faunal biomass for similar faunal groups was not significantly different between the 2 studies. These comparisons indicate a stable system is present in this region. In both studies, highest benthic biomass occurred in BSAW and lowest benthic biomass occurred in $A C W$, indicating that high water column primary production in the spring and summer produces a persistent food supply which influences benthic biomass in the region. Both studies support the conclusion that the northern Bering and Chukchi Seas are detritus-based systems, influenced by variability in sediment composition, water column productivity and current regimes.

\section{CONCLUSIONS}

Sediment sorting, indicative of sediment heterogeneity, percent silt, clay and fine sand composition, and temperature, influence benthic community structure in the northern Bering and Chukchi Seas. Food availability and predation are more variable regulating factors in community structure, although food supply has a direct positive influence on biomass. Benthic faunal structure and biomass have not changed significantly in the area over a $10 \mathrm{yr}$ period, indicating that a seasonally persistent quantity and quality of phytodetrital food supply has a positive impact on population stability in this polar system.

Acknowledgements. We thank the following people for assistance and suggestions over the study period: C. Chu (data analyses), Kris McCumby and K. Coyle (faunal identification), A. Nelson, D. Boisseau, and V Jones (field and laboratory assistance). L. Cooper and 3 anonymous reviewers provided valuable comments that improved the manuscript. Logistical and financial support were provided through the ISHTAR project (NSF-DPP 84-05286) and the University of Alaska Fairbanks (Institute of Marine Science, the Vice-Chancellor for Research and Advanced Study and the Department of Marine Science and Limnology). Additional shiptime was generously provided by Dr George L. Hunt, Jr, University of California, Irvine. We extend, also, our appreciation to the Captain and crew of the RV 'Alpha Helix' for their assistance.

\section{LITERATURE CITED}

Barnes, R. D. (1980). Invertebrate zoology. Saunders College, Philadelphia

Blackburn, T H. (1987). Microbial food webs in sediments. In. Sleigh, M. A. (ed.) The Sea. Ellis Horwood, Chichester, p. $39-58$

Boesch, D. F. (1973). Classification and community structure of macrobenthos of the Hampton Roads area, Virginia. Mar. Biol. 21. 226-244

BrainPower, Inc. (1985). StatView ${ }^{\mathrm{TM}}$. The Graphics Statistics Utility for the MacIntosh ${ }^{\mathrm{TM}}$, Calabasas, Calif., USA 
Butman, C. A. (1987). Larval settlement of soft-sediment invertebrates: the spatial scales of pattern explained by active habitat selection and the emerging role of hydrodynamical processes. Oceanogr. mar. Biol. A. Rev. 25: $113-165$

Clarke, A. (1980). A reappraisal of the concept of metabolic cold adaption in polar marine invertebrates. Biol. J. Linn. Soc. 14: 77-92

Coachman, L. K. (1987). Advection and mixing on the BeringChukchi Shelves. Component A. Advection and mixing of coastal water on high latitude shelves. ISHTAR 1986 Progress Report, Vol. I, Inst. Mar. Sci., Univ. Alaska, Faurbanks, p. $1-42$

Coachman, L. K., Aagaard, K., Tripp, R. B. (1975). Bering Strait: the regional oceanography. University of Washington Press, Seattle

Conover, W. J. (1980). Practical nonparametric statistics. John Wiley \& Sons, New York

Creager, J. S., McManus, D. A. (1967). Geology of the floor of Bering and Chukchi Seas - American studies. In: Hopkins, D. M. (ed.) The Bering Land Bridge. Stanford University Press, Stanford, p. 7-31

Dayton, P. K., Oliver, J. S. (1977). Antarctic soft-bottom benthos in oligotrophic and eutrophic environments. Science 197: 55-58

Fauchald, K., Jumars, P. A. (1979). The diet of worms: a study of polychaete feeding guilds. Oceanogr. mar. Biol. A. Rev. 17: $193-284$

Fay, F. H., Feder, H. M., Stoker, S. W. (1977). An estimation of the impact of the Pacific walrus population on its food resources in the Bering Sea, Final Report. Marine Mammal Commission, Washington, D. C., p. 38

Fay, F. H., Kelly, B. P., Gehnrich, P. H., Sease, J. L., Hoover, A. A. (1984). Modern populations, migrations, demography, trophics, and historical status of the Pacific walrus. Final Report. Inst. Mar. Sci., Univ. Alaska, Fairbanks, p. 142

Feder, H. M., Day, R. H., Jewett, S. C., McCumby, K., McGee, S., Schonberg, S. V (1985). Infauna of the northeastern Bering and southeastern Chukchi Sea. In: Outer Continental Shelf Environmental Assessment Program, Final Reports of Principal Investigators 32. U. S. Dept. of Commerce, NOAA, p. 1-120

Feder, H. M., Jewett, S. C. (1981). Feeding interactions in the eastern Bering Sea with emphasis on the benthos. In: Hood, D. W., Calder, J. A. (eds.) The eastern Bering Sea shelf: oceanography and resources, Vol. 2. University of Washington Press, Seattle, p. 1229-1261

Folk, R. L. (1980). Petrology of sedimentary rocks. Hemphill Publishing Co., Austin

Fresi, E., Gambi, M. C., Focardi, S., Bargagli, R., Baldi, F., Falciai, L. (1983). Benthic community and sediment types: a structural analysis. P.S.Z.N.I. Mar. Ecol. 4: 101-121

Gray, J. S. (1981). The ecology of marine sediments. Cambridge University Press, New York

Grebmeier, J. M. (1987). The ecology of benthic carbon cycling in the northern Bering and Chukchi Seas. Ph. D. dissertation, University of Alaska, Fairbanks

Grebmeier, J. M., McRoy, C. P., Feder, H. M. (1988). Pelagicbenthic coupling on the shelf of the northern Bering and Chukchi Seas. I. Food supply source and benthic biomass. Mar Ecol. Prog. Ser, 48: 57-67

Haflinger, K. (1981). A survey of benthic infaunal communities of the southeastern Bering Sea. In: Hood, D. W., Calder, J. A. (eds.) The eastern Bering Sea shelf: oceanography and resources, Vol 2. University of Washington Press, Seattle, p. 1091-1104

Jewett, S. C., Feder, H. M. (1980). Autumn food of adult starry flounder Platichthys stellatus from the NE Bering Sea and the SE Chukchi Sea. J. Cons. Int. Explor Mer 39: 7-14

Jewett, S. C. Feder, H. M. (1981). Epifaunal invertebrates of the continental shelf of the eastern Bering and Chukchi Seas. In: Hood, D. W., Calder, J. A. (eds.) The eastern Bering Sea shelf: oceanography and resources, Vol. 2. University of Washington Press, Seattle, p. 1131-1155

Kneib, R. T (1985). Predation and disturbance by grass shrimp, Palaemonetes pugio Holthuis, in soft-substratum benthic invertebrate assemblages. J. exp. mar. Biol. Ecol. 93: 91-102

Long, B., Lewis, J. B. (1987). Distribution and community structure of the benthic fauna of the north shore of the Gulf of St. Lawrence described by numerical methods of classification and ordination. Mar Biol. 95: 93-101

McManus, D. A., Kolla, V., Hopkins, D. M., Nelson, C. H (1977). Distribution of bottom sediments on the continental shelf, northern Bering Sea. U.S.G.S. No. 759-C, U. S. Dept of the Interior, Washington. D. C

McManus, D. A., Smyth, C. S. (1970). Turbid bottom water on the continental shelf of the northern Bering Sea. J. Sedim. Petrol. 40: 869-873

McRoy, C. P., Tripp, R. B. (1986). ISHTAR Data Report No. 2, 1985 Hydrographic Data, STD, Nutrients, \& Chlorophyll, Inst. Mar Sci., Univ. Alaska, Fairbanks

McRoy, C. P., Tripp, R. B. (1987). ISHTAR Data Report No. 4 , 1986 Hydrographic Data, STD, Nutrients, \& Chlorophyll, Inst. Mar. Sci., Univ. Alaska, Fairbanks

Nelman, A. A. (1963). Quantitative distribution of benthos on the shelf and upper continental slope in the eastern part of the Bering Sea. In: Soviet Fisheries Investigations in the Northeast Pacific, Part 1, (Israel Program for Scientific Translations, 1968) p. 143-217

Nelson, C. H., Johnson, K. R. (1987). Whales and walruses as tillers of the sea floor Scient. Am. (February): 112-117

Nelson, C. H., Rowland, R. W., Stoker, S. W., Larsen, B. R. (1981). Interplay of physical and biological sedimentary structures of the Bering continental shelf. In: Hood, D. W., Calder, J. A. (eds.) The eastern Bering Sea shelf: oceanography and resources, Vol. 2. University of Washington Press, Seattle, p. 1265-1296

Nerini, M. (1984). A review of gray whale feeding ecology. In Jones, M. L., Swartz, S. L., Leatherwood, S. (eds.) The Gray Whale Eschrichtius robustus. Academic Press, New York, p. $423-450$

Oliver, J. S., Slattery, P. M. (1985). Destruction and opportunity on the sea floor: effects of gray whale feeding. Ecology 66: $1965-1975$

Oliver, J. S., Slattery, P. M., O'Connor, E. F., Lowry, L. F. (1983a). Walrus, Odobenus rosmarus, feeding in the Bering Sea: a benthic perspective. Fish Bull. U. S. 81: 501-512

Oliver, J. S., Slattery, P. M., Silberstein, M. A., O'Connor, E. F. (1983b). A comparison of gray whale, Eschrichtius robustus, feeding in the Bering Sea and Baja California. Fish. Bul. U. S. 81: 513-522

Palmer, M. A. (1988). Epibenthic predators and marine meiofauna: separating predation, disturbance, and hydrodynamic effects. Ecology 69: 1251-1259

Peterson, C. H. (1979). Predation, competitive exclusion, and diversity in the soft-sediment benthic communities of estuaries and lagoons. In: Livingston, R. J. (ed.) Ecological processes in coastal and marine systems. Plenum Press, New York, p. 233-264

Petersen, G. H., Curtis, M. A. (1980). Differences in energy flow through major components of subarctic, temperate and tropical marine shelf ecosystems. Dana 1.53-64

Riddle, M. J. (1988). Patterns in the distribution of macro- 
faunal communities in coral reef sediments on the central Great Barrier Reef. Mar Ecol. Prog. Ser. 47: 281-292

Robert, G. (1979). Benthic molluscan fauna of the St. Lawrence estuary and its ecology as assessed by numerical methods. Naturaliste can. 106: 211-227

Rohlf, F. J., Sokal, R. R. (1969). Statistical tables. W. H. Freeman and Co. San Francisco

Sambrotto, R. N., Goering, J. J., McRoy, C. P. (1984). Large yearly production of phytoplankton in the western Bering Strait. Science 225: 1147-1150

Sanders, H. L., Goudsmit, E. M., Mills, E. L., Hampson, G. E. (1962). A study of the intertidal fauna of Barnstable Harbor, Massachusetts. Limnol. Oceanogr. 7: 63-79

Springer, A. M. (1988). The paradox of pelagic food webs on the Bering-Chukchi Continental Shelf. Ph. D. dissertation, University of Alaska, Fairbanks

Stephenson, W. Williams, W. T., Cook, S. (1972). Computer analyses of Petersen's original data on bottom communities. Ecol. Monogr. 42: 387-415

Stewart, P. L., Pocklington, P., Cunjak, R. A. (1985). Distribution, abundance and diversity of benthic macroinvertebrates on the Canadian continental shelf and slope of southern Davis Strait and Ungava Bay. Arctic 38: 281-291

Stoker, S. W (1978). Benthic invertebrate macrofauna of the eastern continental shelf of the Bering/Chukchi Seas. Ph. D. dissertation, University of Alaska, Fairbanks
Stoker, S. W (1981). Benthic invertebrate macrolauna of the eastern Bering/Chukchi continental shelf. In: Hood, D. W., Calder, J. A. (eds.) The eastern Bering Sea shelf: oceanography and resources, Vol. 2. Univ. Wash. Press, Seattle, p. $1.069-1090$

Valiela, I. (1984). Manne ecological processes. Spnnger-Verlag. New York

Walsh, J. J., McRoy, C. P., Blackburn, T H., Coachman, L. W. Goering, J. J., Nihoul, J. J., Parker, P. L., Springer, A. L., Tripp, R. B., Whitledge, T E., Wirick, C. D., Henricksen, K., Andersen, P. (1987). The role of Bering Strait in the carbon/nitrogen fluxes of polar marine ecosystems. In: Rey, L., Alexander, $V$ (eds.) Proceedings of the Sixth Conference of the Comite Artique International 13-15 May 1985. E. J. Brill, Leiden, The Netherlands

Weston, D. P. (1988). Macrobenthos-sediment relationships on the continental shelf off Cape Hatteras, North Carolina. Cont. Shelf Res. 2: 267-286

White, M. G. (1977). Ecological adaptions by Antarctic poikilotherms to the polar marine environment. In Llano, G. A. (ed.) Adaptions within Antarctic ecosystems. Gulf Publishing Co., Houston, p. 197-208

White, M. G. (1984). Marne benthos. In: Laws, R. M. (ed.) Antarctic ecology, Vol. 2. Academic Press, New York, p. $421-462$ 